\title{
The Relationship Research Between Brand Association, Brand Awareness, Brand Satisfaction, and Brand Loyalty in Three Squirrels' Virtual Image
}

\author{
Yang Chen ${ }^{1, \mathrm{a}, \dagger}$ Haoran Qin ${ }^{2, \mathrm{~b}, \uparrow}$
}

\author{
${ }^{1}$ Coventry University \\ ${ }^{2}$ Inner Mongolia Agricultural University \\ ${ }^{*}$ a Yang Chen.Email:lexichen0808@gmail.com, ${ }^{b}$ Haoran Qin.Email: haoranqin@emails.imau.edu.cn \\ ${ }^{\top}$ These authors contributed equally.
}

\begin{abstract}
In order to explore and verification the existing theory about brand loyalty, this study takes Three Squirrels as an example, further verifies it in the form of online survey, and puts forward a new influencing factor is brand virtual image. For the aim of this study, this study uses the relevant theories about brand loyalty, brand satisfaction, brand awareness, brand association. In addition, SPSS is used to analyse the data by linear regression. The results show that, brand virtual image has a direct and positive influence on brand loyalty and brand satisfaction. Moreover, brand virtual image has an indirect and positive influence on brand loyalty, which through brand satisfaction.
\end{abstract}

Keywords: Brand virtual image, Brand loyalty, Brand satisfaction, Brand awareness, Brand association, Smart PLS.

\section{INTRODUCTION}

With the rapid development of China's economy and the rise of people's fastidiousness on food, leisure snacks have gradually become a necessity for Chinese young consumers. In addition, with the rapid development of China's e-commerce food industry, Generation Y consumers who are keen on online shopping have gradually become the main force in China's e-commerce market. In the era of the outbreak of e-commerce dividends in China in 2012, Zhang Liaoyuan seized the opportunity to set up Three Squirrels, an Internet food company in Wuhu, Anhui, China. Its main business covers all kinds of snacks such as nuts, jerky, and puffed food [1]. Three Squirrels has a unique logo and web design system. It uses the virtual image of three cartoon squirrels to bring consumers a visual experience. Simultaneously, relying on the Internet platform, Three Squirrels fully promoted the virtual sales assistant to help the brand consolidate the brand positioning of the "Forest Food" and won the recognition of the picky consumer groups. Various factors have made Three Squirrels became one of the three giants in the Chinese e-commerce snack market.
Three Squirrels are facing some problems, according to the analysis of the annual Report of Three Squirrels in 2020, the total revenue reached 9.794 billion yuan, down $3.72 \%$ from the same period last year, and the net profit was 301 million yuan (Figure 1) [2]. Judging from the single quarter, in the second quarter, when the performance of Three Squirrels generally grew slowly after the epidemic [3]. Overall, the performance of the three squirrels has been satisfactory.

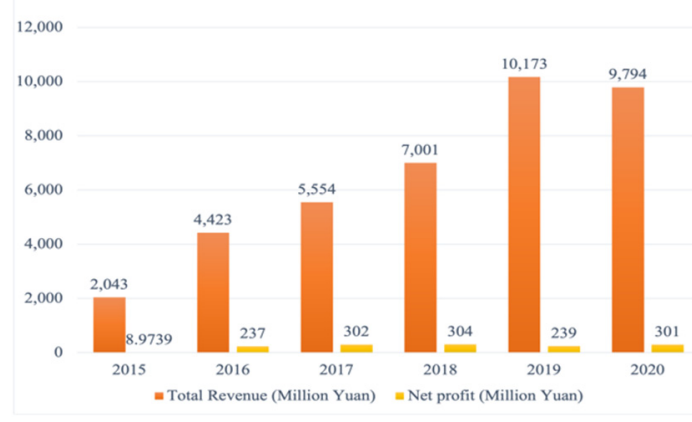

Figure 1 2015-2021 Three Squirrels' Total Revenue and Net profit

Three Squirrels were established for 9 years as a typical e-commerce brand, there are many studies about 
Three Squirrels' success factors. Previous studies mostly focused on its marketing strategy. In 2020, Song $\mathrm{Wu}$ studied the enterprise strategic development of Three Squirrels through Porter's five forces model [4]. In 2017, Jie Zhang analyzed the Three Squirrels' customer satisfaction and customer brand loyalty under the network environment [5]. Nevertheless, few studies involve the virtual image of Three Squirrels.

The virtual image of Three Squirrels is an important part of brand equity. Its diverse visual presentation, like its logo and virtual sales assistants using three squirrels' personification image, enriches consumers' brand association. Three squirrels taking advantage of people's inherent impression of "squirrels love to eat nuts" launched a series of nut snacks. When consumers purchase nut snacks, they are usually associated with Three Squirrels and buy its products. Thereby the brand enhances consumers' brand loyalty.

Compared with other leisure snack companies in the industry, the unique virtual image and humanized customer service have always been the competitive advantages of Three Squirrels. However, with the rapid upgrading of the Internet and consumers' gradual understanding of the marketing routines of Three Squirrels, systematically managing the virtual image gradually becomes a barrier of the Three Squirrels company. Consumers' attitudes to Three Squirrels may change quickly. Marketers should recognize the position of the virtual image in brand assets and clearly notice what it will affect to protect the virtual image continuously as their successful tool. The novelty virtual images can better attract consumers' attention; nevertheless, whether the virtual image will strengthen consumers' loyalty in the long term. This article will survey the brand's target customers group, Generation Y, who likely consume healthy products and willing to pay for hobbies. And collecting the consumers' perceptions of the virtual image, recognizing the virtual image of Three Squirrels, purchase behavior, and other data to analyze the role of the virtual image in constructing consumers' brand associations, brand awareness, brand satisfaction, and brand loyalty.

In order to explore and verification the existing theory about brand loyalty, this paper will be divided into six sections. First, the article goes through the introduction part, which explained the background of Three Squirrels' success and promoted the necessity of researching its unique virtual sales assistants. Second, doing a literature review which focused on the previous study of the concept of brand associations, brand satisfaction, brand awareness, and brand loyalty and the relationship between four basic concepts to support better for the research of virtual image of Three Squirrels from the theoretical aspect. The third is about the survey methods of this study. The fourth part using the SPSS to analyze the data by linear regression about the result from 135 valid questionnaires on the target consumers group of Three Squirrels to analyze and discuss consumers' brand associations, brand satisfaction, brand awareness, and brand loyalty. In the next part, combined with the previous studies, the conclusion shows that the virtual sales assistant image will affect consumers' brand associations, brand awareness, brand satisfaction, which play the important roles in brand loyalty and summarizes virtual brand image of Three Squirrels' managerial implications. The end based on the survey results and the theoretical basis of the predecessors, the article concluded the whole article and discussed about the limitation and future study.

\section{LITERATURE REVIEW}

Over the past decade, most marketing specialists researching brand equity's elements and the relationship between brand associations, brand awareness and brand loyalty to develop the theory on marketing subject. Based on the research background of this article, the article will use the brand association, brand awareness, and brand loyalty included in brand equity theory asserted by Aaker and Keller and the relationship between brand attitude and brand image proposed Keller $[6,7]$. The brand satisfaction influences consumers' loyalty concluded by J. Josko, Brakus. Bernd, H. Schmitt, and Lia Zarantonello in 2009 which based on previous studies will help construct the relationship between brand loyalty and brand satisfaction [8].

\subsection{Brand Associations}

Aaker's proposition that brand equity consists of brand associations, brand loyalty, brand awareness, perceived quality, and other brand assets. Brand association are anything that consumers can memory and linked to a brand and a set of brand associations formed brand image. It likes an information collecting tool to execute brand differentiation and brand extension [9]. Brand Association provides customers reason to buy a brand's products, and it represents a basis for purchasing decisions and brand loyalty [10]. Due to Keller proposed that brand image is a set of brand associations and brand associations including brand attributes, brand benefits, and brand attitudes. Due to most brand associations are related to brand attributes, the target consumer market, and the benefits that consumers need, the brand association affords consumers purchasing reason to form the foundation of brand loyalty and consumers' purchasing decisions [11].

\subsection{Brand Awareness}

Whether consumers can recall or recognize a brand is brand awareness such as linking the brand with the brand name [12]. Brand awareness is indispensable for 
the communications process to emerge, and it brings considerable impacts on consumers' decision-making $[13,14]$. Other scholars, like Pouromid and Iranzadeh claimed that brand awareness has direct effects on brand's equity [15]. Brand awareness affects consumer decision-making. In other words, brand awareness is positively associated with brand loyalty [16]. And Saleem, Rahman, and Umar in 2015 employed pearson correlation, linear regression, and multiple regression tests on the data collected from Pakistan market and infer this result of positive relate [17].

\subsection{Brand Loyalty and Brand Satisfaction}

Brand satisfaction as a strongly related and necessary precursor of brand loyalty influences brand loyalty [18, 19, 20]. In 2009, J. Josko. Brakus Bernd H. Schmitt and Lia Zarantonello said that brand satisfaction has a positive effect on brand loyalty. They draw the conclusion by constructing a brand experience scale and proposed four dimensions: sensory, affective, intellectual, and behavioral [21]. Martisiute, Vilutyte, and Grundey, used the Lithuanian market as an example to systematically analyze and modeling research and came up with the conclusion that customer satisfaction is essential for customer loyalty [22].

In general, these studies emphasize the basic concepts of brand associations, brand awareness, and brand loyalty and related academic concepts and their relationships among brand equity. The article verifies the above pieces of theory to study the influence of the virtual image of Three Squirrels on consumers' brand association (brand image), brand awareness, brand attitude, brand experience, and brand satisfaction on brand loyalty by surveying.

Table 1. Factors Affecting Brand Loyalty

\begin{tabular}{|c|c|c|c|}
\hline Factors & Author(s) & Year & Definition \\
\hline $\begin{array}{l}\text { Brand } \\
\text { Associations }\end{array}$ & $\begin{array}{l}\text { Sasmita et } \\
\text { al }\end{array}$ & 2015 & $\begin{array}{l}\text { The higher the brand } \\
\text { associations in the product, } \\
\text { the more it will be } \\
\text { remembered by the consumer } \\
\text { and be loyal towards the } \\
\text { brand [23]. }\end{array}$ \\
\hline $\begin{array}{l}\text { Brand } \\
\text { Awareness }\end{array}$ & $\begin{array}{l}\text { Nguyen et } \\
\text { al }\end{array}$ & 2011 & $\begin{array}{l}\text { Brand awareness is positively } \\
\text { associated with brand loyalty. }\end{array}$ \\
\hline \multirow[t]{2}{*}{$\begin{array}{l}\text { Brand } \\
\text { Satisfaction }\end{array}$} & $\begin{array}{l}\text { Heskett et } \\
\text { al }\end{array}$ & 1997 & $\begin{array}{l}\text { Profit, growth, customers' } \\
\text { loyalty, customers' } \\
\text { satisfaction, products' and } \\
\text { services benefits, employee } \\
\text { facilities are directly related } \\
\text { [24]. }\end{array}$ \\
\hline & $\begin{array}{l}\text { Brakus et } \\
\text { al }\end{array}$ & 2009 & $\begin{array}{l}\text { Brand satisfaction has a } \\
\text { positive effect on brand } \\
\text { loyalty. }\end{array}$ \\
\hline
\end{tabular}

\section{METHODOLOGY}

\subsection{Data Collection}

This paper uses an online survey, through the analysis of survey data, draw a conclusion. The design of the survey is divided into three parts, including the basic information part, which mainly distinguishes the target customer groups of Three Squirrels. Part II is the consumer loyalty, which involves brand satisfaction, brand awareness, brand association. Part III is the target customer group's cognition and sensory changes of the brand virtual image. This survey covers the target consumer group (Generation Y) of Three Squirrels in China and Chinese in Japan.

\subsection{Administration of Survey}

In this study, the target population mainly covers Inner Mongolia, Hebei, Beijing and other cities in China. 135 questionnaires were collected in the form of anonymous online questionnaires, all of which were valid. The rest of the questionnaires (135) have been used (100 percent) for data analysis using Smart PLS software (version 20).

\section{RESULTS}

\subsection{Demographic Profile Analysis}

The survey respondents were composed of 40 percent male and 60 percent female, which means among the participants in this survey, there are more choices from the perspective of female than male. The age trend is as follows: The post-90s generation had the largest number of respondents ( 57.05 percent) that is followed by the age group of post-80s (17.78 percent), post-00s (16.3 percent), post-70s (6.67 percent) and other age groups.

\subsection{Reliability Test}

Reliability test is regarded as a tool of measurement, which shows the stability and consistency of measuring instruments when repeated measurements [25]. According to Cavana et al., Cronbach alpha as a wellknown method of measuring reliability, it is considered acceptable and good when its range value is greater than 0.70. Results from the Table 2 point out the Cronbach alpha for the five tested constructs were well above 0.70 . Based on the finding, Cronbach alpha for the construct ranged from lowest of 0.911 (Brand Association) to 1.000 (Brand Virtual Image). In conclusion, the outcome concluded that the measurement scales of the constructs were stable and consistent in measuring the constructs. 
Table 2. Reliability of the Constructs

\begin{tabular}{|l|l|l|}
\hline $\begin{array}{l}\text { Construct Reliability and } \\
\text { Validity }\end{array}$ & $\begin{array}{l}\text { Cronbach's } \\
\text { Alpha }\end{array}$ & $\begin{array}{l}\text { Composite } \\
\text { Reliability }\end{array}$ \\
\hline Brand Virtual Image & 1.000 & 1.000 \\
\hline Brand Association & 0.806 & 0.911 \\
\hline Brand Awareness & 0.922 & 0.963 \\
\hline Brand Loyalty & 0.940 & 0.971 \\
\hline Brand Satisfaction & 0.859 & 0.934 \\
\hline
\end{tabular}

\subsection{Validity Test}

Discriminant validity was assessed based on the square root of average variance extracted (AVE) (Table 3 ) and the correlation shared between the construct and other constructs. For each construct, CR was greater than the recommended threshold of 0.7, AVE exceeded the recommended value of 0.5 . Therefore, convergent validity is supported. According to Fornell \& Larcker when the square root of the AVE for each construct is higher than any correlation between this and any other construct, discriminant validity could be achieved [26]. As shown in Table 4, the square roots of the AVE are greater than the correlations among constructs, thereby indicating good discriminant validity. In addition, convergent and discriminant validity, the measurement model could be considered to have construct validity [27].

Table 3. Construct Validity

\begin{tabular}{|l|l|}
\hline & $\begin{array}{l}\text { Average Variance Extracted } \\
\text { (AVE) }\end{array}$ \\
\hline Brand Virtual Image & 1 \\
\hline Brand Association & 0.837 \\
\hline Brand Awareness & 0.928 \\
\hline Brand Loyalty & 0.944 \\
\hline Brand Satisfaction & 0.875 \\
\hline
\end{tabular}

Table 4. Discriminant Validity

\begin{tabular}{|l|l|l|l|l|l|}
\hline & $\begin{array}{l}\text { Brand } \\
\text { Virtual } \\
\text { Image }\end{array}$ & $\begin{array}{l}\text { Brand } \\
\text { Association }\end{array}$ & $\begin{array}{l}\text { Brand } \\
\text { Awareness }\end{array}$ & $\begin{array}{l}\text { Brand } \\
\text { Loyalty }\end{array}$ & $\begin{array}{l}\text { Brand } \\
\text { Satisfaction }\end{array}$ \\
\hline $\begin{array}{l}\text { Brand } \\
\text { Virtual } \\
\text { Image }\end{array}$ & 1 & & & & \\
\hline Brand & 0.55 & 0.915 & & & \\
\hline
\end{tabular}

\begin{tabular}{|l|l|l|l|l|l|}
\hline Association & & & & & \\
\hline $\begin{array}{l}\text { Brand } \\
\text { Awareness }\end{array}$ & 0.479 & 0.742 & 0.963 & & \\
\hline $\begin{array}{l}\text { Brand } \\
\text { Loyalty }\end{array}$ & 0.57 & 0.636 & 0.58 & 0.971 & \\
\hline $\begin{array}{l}\text { Brand } \\
\text { Satisfaction }\end{array}$ & 0.357 & 0.417 & 0.454 & 0.43 & 0.936 \\
\hline
\end{tabular}

\subsection{Factor Loading}

Factor loading's significance assess convergent validity. From Table 5, factor loadings are higher than 0.8 and all significant ( $\mathrm{p}$-value $<0.5 \%$ ).

Table 5. Factor Loading

\begin{tabular}{|l|l|l|l|l|l|}
\hline & $\begin{array}{l}\text { Brand } \\
\text { Awareness }\end{array}$ & $\begin{array}{l}\text { Brand } \\
\text { Associat } \\
\text { ion }\end{array}$ & $\begin{array}{l}\text { Brand } \\
\text { Loyalty }\end{array}$ & $\begin{array}{l}\text { Brand } \\
\text { Satisfactio } \\
n\end{array}$ & $\begin{array}{l}\text { Brand } \\
\text { Virtual } \\
\text { Image }\end{array}$ \\
\hline BA1 & 0.962 & & & & \\
\hline BA2 & 0.964 & & & & \\
\hline BAS1 & & 0.901 & & & \\
\hline BAS2 & & 0.928 & & & \\
\hline BL1 & & & 0.973 & & \\
\hline BL2 & & & 0.97 & & \\
\hline BS1 & & & & 0.923 & \\
\hline BS2 & & & & 0.948 & \\
\hline BVI1 & & & & & 1 \\
\hline
\end{tabular}

\subsection{Final Results}

\subsubsection{Brand Satisfaction}

According to table 6 , the data of brand virtual image to brand satisfaction is 0.857 , indicating that there is a positive correlation between them, that is, brand virtual image has a positive impact on brand satisfaction. Moreover, among all the influencing factors, brand virtual image has the most important influence on brand satisfaction, and it is also the only influence on brand satisfaction.

Table 6. (O)\&P

\begin{tabular}{|c|c|c|c|}
\hline $\begin{array}{l}\text { Independent } \\
\text { variable }\end{array}$ & $\begin{array}{l}\text { Dependent } \\
\text { variable }\end{array}$ & $\begin{array}{l}\text { Original } \\
\text { Sample (O) }\end{array}$ & $\begin{array}{l}\mathrm{P} \\
\text { Values }\end{array}$ \\
\hline $\begin{array}{l}\text { Brand Virtual } \\
\text { Image }\end{array}$ & $\begin{array}{l}\text { Brand } \\
\text { Satisfaction }\end{array}$ & 0.857 & 0 \\
\hline
\end{tabular}




\subsubsection{Brand Loyalty}

According to the above two tables, brand association, brand satisfaction, brand awareness has a direct impact on brand loyalty, while brand virtual image not only has a direct impact on brand loyalty, but also indirectly affects brand loyalty through its impact on brand satisfaction.

As shown in table 7, brand awareness has the greatest impact on brand loyalty (0.776), but its $\mathrm{P}$ Values $=0.292(\mathrm{P}$ Values $>5 \%)$, indicating that brand awareness has no effect on brand loyalty. Hence, only consider the first three effects.

Table 7. Direct effect

\begin{tabular}{|c|c|c|c|}
\hline $\begin{array}{l}\text { Independent } \\
\text { variable }\end{array}$ & $\begin{array}{l}\text { Dependent } \\
\text { variable }\end{array}$ & $\begin{array}{l}\text { Original } \\
\text { Sample (O) }\end{array}$ & \begin{tabular}{|l}
$\mathrm{P}$ \\
Values
\end{tabular} \\
\hline $\begin{array}{l}\text { Brand } \\
\text { Association }\end{array}$ & Brand Loyalty & 0.715 & 0.01 \\
\hline $\begin{array}{l}\text { Brand Virtual } \\
\text { Image }\end{array}$ & Brand Loyalty & 0.776 & 0.01 \\
\hline $\begin{array}{l}\text { Brand } \\
\text { Satisfaction }\end{array}$ & Brand Loyalty & 0.629 & 0.048 \\
\hline Brand Awareness & Brand Loyalty & 0.856 & 0.292 \\
\hline
\end{tabular}

\section{DISCUSSION}

\subsection{Result discussion}

This study indicates a brand association, brand satisfaction, and brand awareness directly impact brand loyalty. Simultaneously, the brand virtual image directly impacts brand loyalty and indirectly affects brand loyalty through its impact on brand satisfaction. And the results prove the theory from former scholars that brand associations, brand awareness, brand experience, and brand satisfaction are positively associated with brand loyalty. And brand image, brand satisfaction are the key determinants that directly influence brand loyalty. The results also provide new conclusions that the virtual image affects consumers' purchase behavior and loyalty to the brand. And the brand virtual image has the greatest impact on brand satisfaction, and brand virtual image, directly and indirectly, affects brand loyalty (Figure 2).

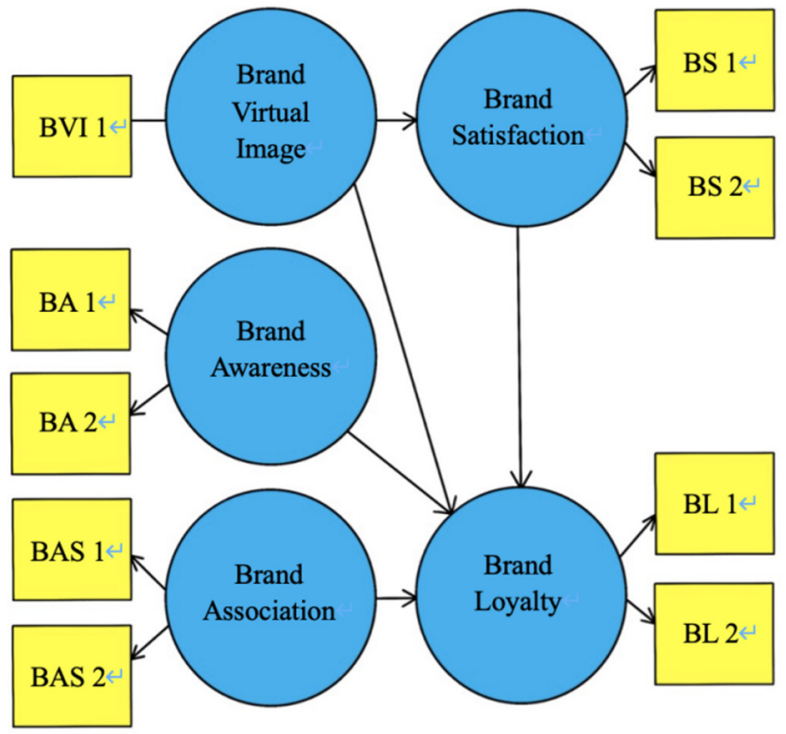

Figure 2 Direct and indirect influencing factors of Brand loyalty

In a theoretical sense, because the brand virtual image has the greatest impact on brand satisfaction and brand loyalty, the brand virtual image is a significant influencing factor. In a practical sense, Three Squirrels grasps the psychology of consumer satisfaction and loyalty by establishing its unique virtual image and indirectly brings huge benefits for the company. Hence, the strategy of establishing the virtual image of Three Squirrels is correct and successful. Therefore, establishing the brand virtual image is worthy of other similar brand enterprises to learn and learn from.

\subsection{Managerial implications}

Marketers and managers need to pay attention to the virtual image, which will significantly influence the brand satisfaction to ensure and maintain the company benefits and long-term benefits since brand loyalty affects the company's profit and gives a competitive ability [28]. For relatively new companies, like Three Squirrels, who use virtual images as brand sales assistants, virtual images can effectively help consumers build brand associations and enrich brand awareness. Meanwhile, marketers and managers should pay attention to the changes of virtual images in consumer perceptions to manage brand image. For marketers and managers, the brand virtual image will affect consumers' loyalty and purchase behavior, so managing virtual images can create long-term benefits and economic value for enterprises.

\subsection{Limitations and future research}

Due to the limited survey data collection in this article, this research only 130 data from Three Squirrels' target customers, so that study just on the relationship 
between brand associations, brand awareness, and brand loyalty, as well as the relationship between brand image, brand satisfaction, and brand loyalty. However, according to previous scholars' research, brand association, brand awareness, and brand loyalty are part of brand equity which is an intangible asset. Future research can further test the relationship between brand virtual image and brand equity to explore more systematic management of brand virtual image since the virtual image is a crucial component of a brand's intangible assets.

\section{CONCLUSION}

Three Squirrels, one of the three giants leisure food brand of the Chinese e-commerce snack market, uses the virtual image of three cartoon squirrels to bring consumers a visual experience which is their significant symbol remembered by consumers. This research studied the relationship between brand associations, brand awareness, brand satisfaction, and brand loyalty by surveying and collecting the data from 135 Three Squirrels' target consumers and using SPSS finished linear regression analyses. Consequently, the study result indicates a brand association, brand satisfaction, and brand awareness directly impact brand loyalty which verified predecessors' theory, and the virtual image, directly and indirectly, influence consumers' purchase behavior and loyalty to the brand, which is the new conclusion extracted from this survey case study. Companies like Three Squirrels use virtual images as brand sales assistants is an effective way to construct consumers' brand associations and enrich brand awareness. For Three Squirrels and other marketers and managers, the brand virtual image will affect consumers' loyalty and purchase behavior. Managing virtual images can create long-term benefits and economic value for enterprises. Three Squirrels should maintain the virtual image as their brand important intangible assets and manage it systematically. The paper illuminates the relationship between brand association, brand awareness, brand satisfaction, and brand loyalty by studying the virtual image. The study concludes that a new conclusion about the virtual image affects brand loyalty which would guide the companies who use the virtual image to improve brand management.

\section{REFERENCES}

[1] "Three Squirrels Official Website." Three Squirrels, www.3songshu.com/. Accessed 24 Apr. 2021

[2] Three Squirrels Co., Ltd. Annual Report 2020. 26 Mar. 2021, pdf.dfcfw.com/pdf/H2_AN202103261477034833 1.pdf?1616790104000.pdf.
[3] Three Squirrel Co., Ltd. Semi-Annual Report 2020. $20 \quad$ Aug. 2020, pdf.dfcfw.com/pdf/H2_AN202008201399983774_ 1.pdf..

[4] Zhang, Chun, and Song Wu. "Discussion on the Strategic Development of Emerging Internet Companies Based on E-Commerce PlatformsTaking Three Squirrels as an Example." Guangxi Quality Supervision Guide Periodical, no. 11, 2020, doi:CNKI:SUN:GXZL.0.2020-11-060.

[5] Zhang, Jie. "Analysis of Brand Loyalty Under the Network Environment-Take Anhui Three Squirrels E-commerce Limited Company for Instance." International Conference on Education Innovation and Social Science (ICEISS 2017). Atlantis Press, 2017.

[6] Aaker, David A. Managing brand equity. simon and schuster, 2009.

[7] Keller, Kevin Lane. "Conceptualizing, measuring, and managing customer-based brand equity." Journal of marketing 57.1 (1993): 1-22.

[8] Brakus, J. Joško, Bernd H. Schmitt, and Lia Zarantonello. "Brand experience: what is it? How is it measured? Does it affect loyalty?." Journal of marketing 73.3 (2009): 52-68.

[9] Van Osselaer, Stijn MJ, and Chris Janiszewski. "Two ways of learning brand associations." Journal of Consumer Research 28.2 (2001): 202-223.

[10] Phong, L., et al. "Relationship between brand association and customer loyalty: The case of online retail industry." Management Science Letters 10.7 (2020): 1543-1552.

[11] Wright, Len Tiu, Cindy Millman, and Lynn M. Martin. "Research issues in building brand equity and global brands in the PC market." Journal of Marketing Management 23.1-2 (2007): 137-155.

[12] Keller, Kevin Lane, M. G. Parameswaran, and Isaac Jacob. Strategic brand management: Building, measuring, and managing brand equity. Pearson Education India, 2011.

[13] Macdonald, Emma, and Byron Sharp. Management perceptions of the importance of brand awareness as an indication of advertising effectiveness. Diss. Massey University, Department of Marketing, 2003.

[14] Huang, Rong, and Emine Sarigöllü. "How brand awareness relates to market outcome, brand equity, and the marketing mix." Fashion branding and consumer behaviors. Springer, New York, NY, 2014. 113-132. 
[15] Pouromid, Behnaz, and Soleyman Iranzadeh. "The evaluation of the factors affects on the brand equity of Pars Khazar household appliances based on the vision of female consumer." Middle-East Journal of Scientific Research 12.8 (2012): 1050-1055.

[16] Nguyen, Tho D., Nigel J. Barrett, and Kenneth E. Miller. "Brand loyalty in emerging markets." Marketing Intelligence \& Planning (2011).

[17] Saleem, Salman, Saleem Ur Rahman, and Rana Muhammad Umar. "Measuring customer based beverage brand equity: Investigating the relationship between perceived quality, brand awareness, brand image, and brand loyalty." International Journal of Marketing Studies 7.1 (2015): 66 .

[18] Sivadas, Eugene, and Jamie L. Baker-Prewitt. "An examination of the relationship between service quality, customer satisfaction, and store loyalty." International Journal of Retail \& Distribution Management (2000).

[19] Taylor, Steven A., and Thomas L. Baker. "An assessment of the relationship between service quality and customer satisfaction in the formation of consumers' purchase intentions." Journal of retailing 70.2 (1994): 163-178.

[20] Fornell, Claes. "A national customer satisfaction barometer: The Swedish experience." Journal of marketing 56.1 (1992): 6-21.

[21] Brakus, J. Joško, Bernd H. Schmitt, and Lia Zarantonello. "Brand experience: what is it? How is it measured? Does it affect loyalty?." Journal of marketing 73.3 (2009): 52-68.

[22] Martisiute, Sandra, Gabriele Vilutyte, and Dainora Grundey. "Product or brand? how interrelationship between customer satisfaction and customer loyalty work." European Journal of Interdisciplinary Studies 2.1 (2010): 5.

[23] Sasmita, Jumiati, and Norazah Mohd Suki. "Young consumers' insights on brand equity: Effects of brand association, brand loyalty, brand awareness, and brand image." International Journal of Retail \& Distribution Management (2015).

[24] JL, Heskett, E. W. Sasser, and L. A. Schlesinger. "The Service Profit Chain: How Leading Companies Link Profit and Growth to Loyalty, Satisfaction and Value." (1997).

[25]Cavana, Robert, Brian Delahaye, and Uma Sekeran. Applied business research: Qualitative and quantitative methods. John Wiley \& Sons, 2001.

[26] Fornell, Claes, and David F. Larcker. "Evaluating structural equation models with unobservable variables and measurement error." Journal of marketing research 18.1 (1981): 39-50.

[27] Hair, J. F., et al. "Multivariate Data Analysis with Readings, 3-rd edition." (1992): 235.

[28] Anderson, Eugene W., and Mary W. Sullivan. "The antecedents and consequences of customer satisfaction for firms." Marketing science 12.2 (1993): 125-143. 